\title{
ANALISIS PENGEMBANGAN PRODUK BERBASIS QUALITY FUNCTION DEPLOYMENT (QFD) (STUDI KASUS PADA PRODUK SUSU PT MSA)
}

\author{
Okky Rizkia Yustian \\ Fakultas Bisnis dan Manajemen, Universitas Widyatama \\ okky.rizkia@widyatama.ac.id
}

\begin{abstract}
Product developments are motivated by science and technology, change of consumer's demands, competition, and requirement to improve profit. This research is intended to figure out and analyze the tools applied in the PT MSA's product development and its alternatives. Quality Function Deployment (QFD) is used to determine product attributes for consumer's demand, company's performance, level of interest, technical parameters, requirement of process, and quality procedures to improve the products. This research is designed as a quantitative research method. QFD application in PT MSA results 15 product attributes, which are demanded by consumers. Those attributes are interpreted through 9 technical parameters in House of Quality (HOQ) for packaged fresh milk, and 15 product attributes for yoghurt. Based on the priority analysis, PT MSA will conduct their business decision to develop yoghurt product, which is expected to increase the total sales.
\end{abstract}

Keywords: product development, quality function deployment, business decision

\section{PENDAHULUAN}

Selama ini masyarakat Lembang menyetorkan perahan susu murninya ke Koperasi Peternak Susu Bandung Utara (KPSBU). Koperasi peternak sapi ini didirikan karena kesadaran akan potensi yang sangat besar di daerah Lembang. KPSBU juga merupakan salah satu penyumbang susu terbanyak kepada IPS (Industri Pengolahan Susu) di Indonesia. PT MSA juga merupakan anggota yang menghasilkan susu terbanyak urutan kedua di KPSBU. Berdasarkan data internal PT MSA, dalam beberapa tahun terakhir harga susu tidak mengalami kenaikan yang signifikan, namun faktor-faktor produksi untuk memproduksi susu mengalami kenaikan harga, antara lain bahan baku. Pada umumnya kenaikan bahan baku bisa diatasi dengan ikut menaikkan harga produk. Namun terdapat kebijakan pemerintah yang membuat para peternak secara tidak langsung harus menyetorkan susunya kepada koperasi untuk disalurkan ke Industri Pengolahan Susu (IPS), sehingga membuat harga susu menjadi sulit untuk naik karena ditentukan oleh kontrak antara koperasi dan Industri Pengolahan Susu (IPS). Oleh karena itu PT MSA mengalami penurunan laba. Adanya permasalahan bahwa susu segar cepat basi membuat PT MSA tidak bisa menjual langsung kepada konsumen lain selain KPSBU. Apabila 
keadaan ini berlangsung secara jangka panjang, maka laba PT MSA akan semakin menurun. Hal ini menimbulkan risiko adanya kerugian di masa yang akan datang dan tujuan perusahaan tidak akan tercapai. Permasalahan penurunan laba yang disebabkan kenaikan harga bahan baku ini perlu diantisipasi dengan perumusan strategi yang baru (Artiprasetyo 2009), antara lain memanfaatkan teknologi dan menciptakan pelanggan baru dengan memproses susu segar menjadi produk baru. Proses ini (misalnya pasteurisasi) akan meningkatkan value susu, membuat susu menjadi tahan lebih lama dan membuat susu tersebut lebih flexible untuk dikembangkan menjadi produk baru. Pengembangan produk merupakan strategi pemasaran yang memerlukan penciptaan produk baru yang dipasarkan, melalui aplikasi teknologi baru kedalam produk yang dapat dipasarkan (Crawford dan Benedetto 2006). Karena kenaikan harga produksi susu tidak dapat diimbangi dengan penjualan susu kepada KPSBU, maka PT MSA akan melakukan pengembangan produk susu untuk meningkatkan value produk susu dan harga jual produk tersebut. Produk susu yang akan diproduksi akan dijual langsung ke konsumen bukan kepada KPSBU, sehingga perlu dikembangkan produk yang benar-benar dibutuhkan dan diminati oleh konsumen.

PT MSA akan menggunakan pengembangan produk dengan metode Quality Function Deployment (QFD). QFD adalah metode perencanaan dan pengembangan produk/jasa secara terstruktur yang memungkinkan tim pengembang mendefinisikan secara jelas kebutuhan dan harapan tersebut dan mengevaluasi kemampuan produk atau jasa secara sistematik untuk memenuhi kebutuhan dan harapan tersebut (Ariani 2008). Penggunaan metode ini diharapkan akan menghasilkan produk yang sesuai dengan harapan dan keinginan konsumen, sehingga terjadi peningkatan penjualan susu untuk mengimbangi kenaikan harga faktor produksi. Dalam metode $Q F D$, dilakukan suatu kegiatan benchmarking untuk mengetahui keunggulan dan kelemahan suatu produk dibandingkan dengan produk pesaing lainnya. Sistem ini akan meningkatkan keselurahan kualitas menuju pencapaian keunggulan bersaing yang berorientasi pada kepuasan pelanggan dengan melibatkan seluruh anggota organisasi. Hasil dari implementasi QFD akan menghasilkan suatu rumah mutu (House Of Quality/HOQ) yang akan menyediakan informasi dalam pengembangan produk. Alat analisis ini diharapkan dapat menjembatani proses peningkatan kualitas produk susu murni berdasarkan aspek bauran pemasaran dengan selera pasar. Hasil pengembangan produk susu murni berdasarkan bauran pemasaran diharapkan bisa menjadi solusi atas permasalahan pengembangan usaha, sehingga dapat menjadi komoditas yang potensial dan dapat bersaing.

Dalam penelitian ini, penulis akan membandingkan antara produk susu murni dalam kemasan dan yoghurt. Dalam proses pengolahan dan pemasaran susu murni dalam kemasan, tantangan terbesarnya adalah masih sulitnya mengubah kebiasaan konsumsi susu masyarakat yang selama ini masih suka produk susu kental manis. Padahal di berbagai negara maju, susu segar dalam kemasan menjadi pilihan utama. Hal ini juga ditunjang oleh budaya minum susu untuk kepentingan kesehatan yang sudah memasyarakat. 
Berdasarkan uraian uraian di atas, maka pertanyaan dalam penelitian ini dapat dirumuskan sebagai berikut: (1) bagaimana QFD digunakan dalam analisis pengembangan produk pada PT MSA? (2) bagaimana hasil analisis QFD dalam analisis pengembangan produk susu murni kemasan dan yoghurt? (3) bagaimana keputusan bisnis yang dibuat berdasarkan analisis QFD oleh PT MSA? (4) bagaimana implementasi keputusan bisnis yang dibuat berdasarkan analisis QFD oleh PT MSA?

Hasil penelitian ini diharapkan akan memberikan sumbangan pemikiran sebagai bahan masukan bagi perusahaan untuk mengetahui keinginan konsumen dan strategi pengembangan produk. Hasil penelitian ini juga dapat digunakan sebagai bahan pertimbangan bagi pihak pemilik dan pengelola perusahaan dalam membuat keputusan yang bermanfaat bagi perkembangan dan kemajuan perusahaan dimasa yang akan datang. Bagi ranah akademis, penelitian ini akan memberikan kontribusi terhadap perkembangan penerapan metode Quality Function Deployment (QFD) dan referensi bagi peneliti lain.

\section{TELAAH PUSTAKA}

\section{Produk Baru}

Produk baru dapat meliputi produk asli, produk yang ditingkatkan, produk yang dimodifikasi dan merek baru. Terdapat enam kategori produk baru, yaitu produk baru bagi dunia, lini produk baru, tambahan pada lini produk yang telah ada, perbaikan dan revisi produk yang telah ada, penentuan kembali posisi (repositioining) dan pengurangan biaya (Crawford dan Benedetto 2006). Menurut Kotler dan Armstrong (dalam Kotler dan Kevin 2009), pengembangan produk baru diartikan sebagai pengembangkan konsep produk menjadi produk fisik agar meyakinkan bahwa gagasan produk dapat diubah menjadi produk yang dapat diwujudkan. Pengembangan produk dapat berupa perbaikan dari produk yang sudah ada atau berusaha menciptakan produk baru untuk diproses dan dipasarkan dengan perubahan-perubahan yang terjadi pada pasar saat ini.

\section{Quality Function Deployment (QFD)}

Quality function deployment didefinisikan sebagai suatu proses atau mekanisme terstruktur untuk menentukan kebutuhan pelanggan dan menerjemahkan kebutuhan-kebutuhan itu ke dalam spesifikasi kebutuhan teknis yang relevan, dimana masing-masing area fungsional dan tingkat organisasi dapat mengerti serta bertindak. QFD juga mencakup pemantauan dan pengendalian yang tepat dari proses manufaktur (Gaspersz 2006).

Titik awal QFD adalah pelanggan serta keinginan dan kebutuhan dari pelanggan. Dalam hal ini, QFD disebut sebagai “suara dari pelanggan” (voice of the customer), sehingga pekerjaan dari tim QFD adalah mendengar suara dari pelanggan. 
Proses QFD dimulai dari suara pelanggan dan kemudian berlanjut melalui empat aktivitas utama yaitu perencanaan produk, desain produk, perencanaan proses dan perencanaan pengendalian proses (Gaspersz 2006). Adapun tahapan implementasi Quality function deployment $(Q F D)$ secara umum terdiri dari tiga fase yaitu fase pengumpulan suara konsumen, fase penyusunan rumah kualitas (House of Quality) serta fase analisis dan interpretasi.

Melalui pemanfaatan $Q F D$, tenaga pemasaran dan tim perancang produk dapat menjawab pertanyaan mengenai atribut apa yang kritis bagi pelanggan. Ciriciri (features) dari desain produk yang akan dikembangkan tidak hanya didasarkan pada selera, opini dan keinginan individu dalam perusahaan tersebut, tetapi juga dari "suara” calon pelanggan atau pelanggan yang sangat banyak dan beragam. Demikian pula faktor-faktor kompleks lain seperti persaingan bisnis yang sangat ketat, perlu juga menjadi bahan pertimbangan. Tujuan dari QFD sendiri tidak hanya memenuhi sebanyak mungkin harapan-harapan pelanggan, tetapi juga berusaha melampaui harapan-harapan pelanggan sebagai cara untuk berkompetisi dengan pesaing.

\section{Matriks House of Quality}

Dalam $Q F D$, dikembangkan suatu matriks yang saling berhubungan untuk menetapkan kaitan antara keinginan pelanggan dan parameter teknik dari produk atau jasa. Matriks ini disebut sebagai matriks House of Quality.

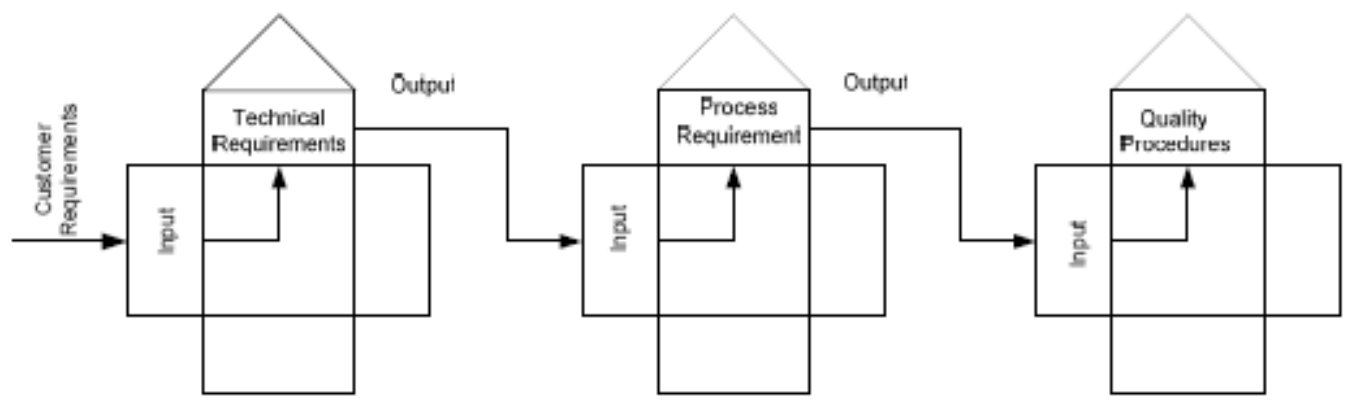

Sumber: Groover (2014)

\section{Gambar 1 \\ Pengembangan Matriks House of Quality}

Banyak atau sedikitnya matriks digunakan dalam analisis sangat tergantung pada kebutuhan. Pada matriks paling kiri, terdiri dari daftar input yang berisi keinginan dari konsumen. Masukan diterjemahkan ke dalam output yang teknis, kemudian dimasukkan di bagian tengah dari matriks itu. Output dari matriks tengah menjadi input untuk matriks bagian kanan, seperti terlihat pada Gambar 1.

\section{Atribut Produk}

Atribut produk merupakan unsur-unsur produk yang sering dijadikan dasar pengambilan keputusan oleh konsumen untuk melakukan pembelian (Tjiptono 2007). Atribut produk mempunyai pengaruh yang cukup besar pada persepsi konsumen 
terhadap suatu produk, karena di dalamnya terdapat unsur-unsur yang memberikan manfaat atas produk itu sendiri. Oleh karena itu, semakin kuat manfaaat dan keunggulan atribut atas sebuah produk, maka akan semakin memberi nilai lebih atas suatu produk.

\section{Kerangka Penelitian}

Penelitian ini diawali dari analisis strength, weakness, opportunity, and threat (SWOT), yaitu dengan menganalisis kekuatan (strength) yang dimilki oleh susu murni. Faktor kekuatan dari susu murni adalah tersedianya sumber daya alam yang banyak, iklim yang mendukung, masa panen susu yang tidak tergantung musim, susu tanpa bahan pengawet dan diolah dengan sangat higienis. Selain memiliki kekuatan (strength), susu murni tentu memiliki kelemahan (weakness) antara lain timbulnya produk cacat atau gagal dalam setiap produksi dan banyaknya persaingan. Produk cacat ini disebabkan karena tidak menggunakan bahan pengawet, sehingga susu murni tidak dapat bertahan lama. Peluang (opportunity) pada susu murni adalah produksi yang dihasilkan segar dan berkualitas, harga barang yang menarik dan terjangkau, serta dapat menjual produk dengan kemasan (cup). Hambatan (threat) adalah susu murni yang dijual setiap harinya tidak selalu habis, kurangnya informasi tentang peluang pasar dan produk ini tidak menjangkau supermarket atau toko kelontong.

Berdasarkan analisis SWOT, maka disimpulkan bahwa diperlukan perbaikan/pengembangan produk susu murni. Pengembangan produk susu murni dilakukan dengan menggunakan $Q F D$, yang diawali dengan menggali apa yang menjadi kebutuhan dan keinginan konsumen akan produk susu murni. Setelah diidentifkasi apa yang dibutuhkan dan diinginkan konsumen, dibuat matriks perencanaan yang berisi hubungan antara atribut kebutuhan dan keinginan konsumen dengan karakteristik teknis tertentu. Selain itu dilakukan benchmarking dengan mencari referensi pesaing serta dilakukan pembandingan kinerja susu murni aktual dengan target. Selanjutnya dilakukan analisis fokus pengembangan produk berdasarkan bauran pemasaran, yaitu produk, harga, tempat/saluran distribusi dan promosi. 


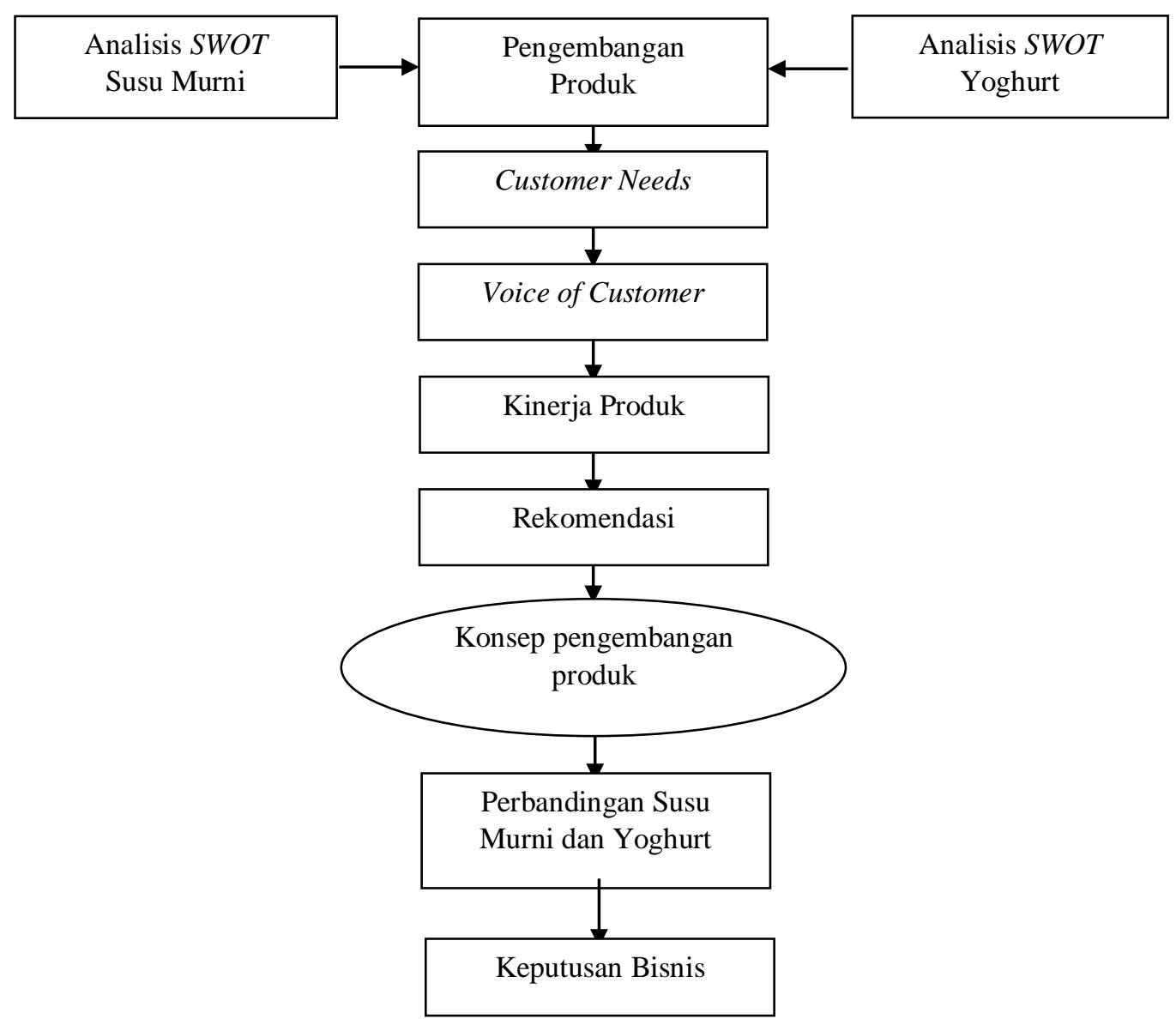

Gambar 2

Skema Kerangka Pemikiran

\section{METODA PENELITIAN}

\section{Desain penelitian}

Penelitian ini termasuk dalam jenis penelitian action research, yang digunakan untuk memperkuat komunitas lokal atau yang mewakilinya dengan cara melibatkan sekaligus mendorong masyarakat atau perorangan untuk mengenali potensi dan permasalahan yang ada di desa, komunitas atau usaha mereka, sehingga timbul inisiatif untuk melakukan tindakan penyelesaian masalahnya sendiri. Penelitian action research adalah penelitian yang ditujukan untuk mengembangkan keterampilan-keterampilan baru, strategi baru atau pendekatan baru untuk memecahkan masalah dengan penerapan langsung di dunia kerja atau dunia aktual yang lain (Aries 2010).

Lewin (dalam Hermawan 2010) mengembangkan action research atas dasar konsep bahwa action research terdiri dari empat komponen pokok yang juga menunjukkan langkah-langkah yaitu perencanaan (planning), tindakan (acting), pengamatan (observing) dan refleksi (reflecting). Hubungan antara keempat 
komponen tersebut menunjukkan sebuah siklus atau kegiatan yang berulang. Siklus inilah yang sebetulnya menjadi salah satu ciri utama dari penelitian tindakan, yaitu bahwa penelitian tindakan harus dilaksanakan dalam bentuk siklus, bukan hanya satu kali intervensi saja (Arikunto 2006).

Objek penelitian ini adalah PT MSA. Di tahun 2009 PT MSA berkembang sebagai salah satu penghasil susu terbesar di kawasan Lembang yang menyetorkan susunya sebanyak 400 liter per hari kepada KPSBU, yang nantinya akan dijual kepada salah satu IPS (Industri Pengolahan Susu) di Indonesia. Pada Tahun 2011 MSA mendaftarkan ijin usahanya dalam bentuk Perseroan Terbatas (PT) menjadi PT MSA, dan saat ini memiliki 25 orang tenaga kerja.

Penelitian ini menggunakan data primer dan data sekunder, baik yang bersifat kualitatif maupun kuantitatif. Data primer diperoleh melalui wawancara dan pengisian kuesioner oleh pemilik dan pengelola PT MSA, serta expert judgment dan pengamatan langsung di lapangan. Sedangkan data sekunder diperoleh dari bahan pustaka dan literatur yang relevan. Menurut Sugiyono (2013) ada beberapa teknik pengumpulan data, dalam penelitian itu teknik pengumpulan data dilakukan melalui penelitian lapangan (field research) maupun penelitian kepustakaan (library research). Penelitian ini menggunakan teknik pengumpulan data yang dilakukan melalui observasi, wawancara mendalam, penyebaran kuesioner dan triangulasi. Data dan informasi primer untuk menyusun House of Quality (Rumah Kualitas) dan pemilihan atribut produk susu murni dikumpulkan melalui wawancara dengan UKM susu murni yang berada di bawah naungan KPSBU. Wawancara dilakukan kepada para pengusaha, ketua koperasi, bagian bina sarana produksi dan bagian humas. Sedangkan kuesioner diberikan kepada konsumen pembeli produk susu murni.

\section{Tahapan Analisis Quality Function Deployment (QFD)}

Analisis QFD yang digunakan adalah analisis QFD berantai, artinya analisis matriks House of Quality (HOQ) yang menggunakan lebih dari satu matriks HOQ. Analisis QFD dapat menggunakan lebih dari satu matriks $H O Q$ dengan tujuan agar output dari QFD lebih teknis dan spesifik. Pada penelitian ini menggunakan tiga matriks $H O Q$ untuk menghasilkan hasil analisis yang optimal. Adapun langkah-langkah pembuatan matriks HOQ adalah sebagai berikut:

1. Menentukan derajat kepentingan tiap atribut:

$$
\begin{aligned}
& x=\frac{\sum_{i=1}^{n} D K i}{n} \ldots \ldots \ldots \ldots \ldots \ldots \ldots \ldots \ldots \ldots \ldots \ldots \ldots \ldots \ldots \\
& \text { keterangan: } \\
& \text { DKi }=\text { Derajat Kepentingan responden ke-i } \\
& \mathrm{n} \quad=\text { jumlah responden. }
\end{aligned}
$$


2. Menentukan kinerja atribut produk:

$$
x=\frac{\sum_{i=1}^{n} K i}{n}
$$

keterangan:

$\mathrm{Ki}=$ Kepuasan responden ke-i

$\mathrm{n} \quad=$ jumlah responden.

3. Menentukan nilai target dari setiap atribut produk.

4. Menentukan rasio perbaikan.

$$
\text { Rasio perbaikan }=\frac{\text { Nilai target }}{\text { Kinerja produk }}
$$

5. Menentukan sales point.

6. Menentukan bobot dari setiap atribut produk.

Bobot = Derajat Kepentingan $\times$ Rasio Perbaikan $\times$ Sales Point . .4

7. Menentukan normalisasi bobot.

8. Identifikasi parameter teknik (technical requirements).

9. Menentukan interaksi antara keinginan konsumen dengan parameter teknik.

a. Nilai matriks interaksi keinginan konsumen dengan parameter teknik:

$\mathrm{KT}_{\mathrm{i}}=\Sigma \mathrm{BT}_{\mathrm{i}} \times \mathrm{H}_{\mathrm{i}}$

keterangan:

$\mathrm{KTi}=$ Nilai absolut parameter teknik setiap atribut,

$\mathrm{BTi}=$ Kepentingan relatif (bobot) keinginan konsumen yang memiliki hubungan dengan atribut produk,

$\mathrm{Hi}=$ Nilai hubungan keinginan konsumen yang memiliki hubungan dengan atribut produk.

b. Prioritas parameter teknik berdasar kepentingan relatif

$$
\text { Kepentingan relatif }=\frac{\text { Parameter teknik absolut }}{\sum \text { Parameter teknik absolut }} \quad \%
$$
6

\section{Tahapan Analisis Rancangan Implikasi Masalah}

Adapun untuk memecahkan permasalahan, dilakukan tahapan-tahapan analisis sebagai berikut ini.

1. Identifikasi masalah.

2. Proses pengumpulan data mengenai atribut kebutuhan dan keinginan konsumen dengan cara wawancara kepada pihak yang dianggap bisa menjawab permasalahan.

3. Identifikasi atribut kebutuhan dan keinginan konsumen akan produk susu murni, dimana atribut ini digunakan untuk penyusunan kuesioner.

4. Penyusunan dan penyebaran kuesioner hasil dari penelitian pendahuluan kepada konsumen.

5. Pengolahan data hasil kuesioner dengan menggunakan metode Borda dan Comparative Performance Index (CPI). 
6. Bobot atribut juga dapat dijadikan skala prioritas perbaikan, kemudian dilakukan perbandingan dengan pesaing yang dapat diperoleh melalui referensi pesaing.

7. Penerapan metode $Q F D$, dengan membuat matriks $H O Q$.

8. Perbaikan dan pengembangan produk sesuai dengan keinginan konsumen.

9. Pemilihan antara produk susu murni kemasan atau produk yoghurt.

10. Implementasi hasil dari pemilihan produk.

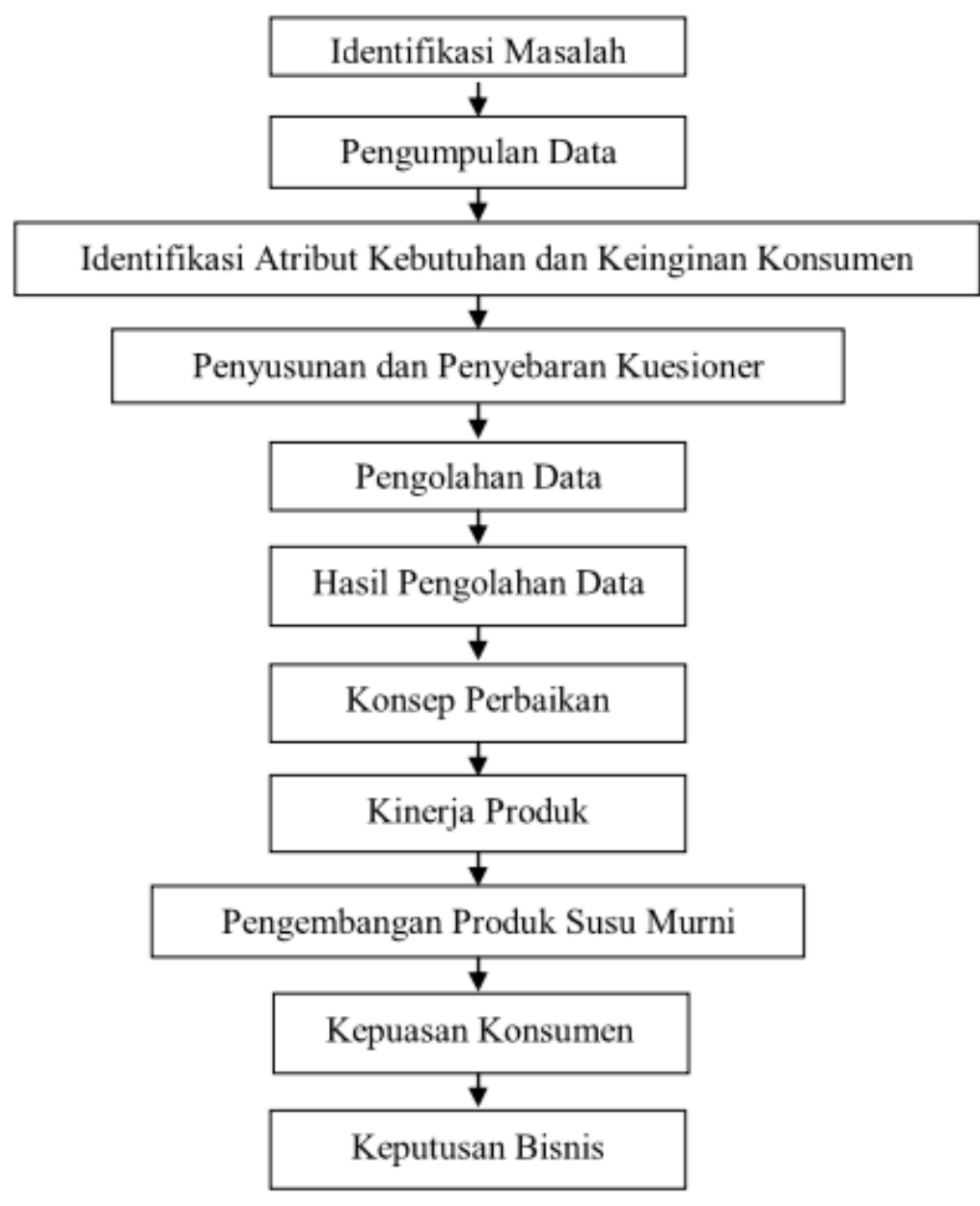

Gambar 3

Skema Tahapan Analisis Rancangan Implikasi Masalah

\section{HASIL DAN PEMBAHASAN}

\section{Analisis QFD dalam Pengembangan Produk Susu Murni Kemasan dan Yoghurt}

Analisis QFD yang digunakan dalam pengembangan produk susu murni kemasan dan yoghurt PT MSA adalah QFD berantai, yaitu analisis House of Quality (HOQ) yang menggunakan lebih dari satu matriks HOQ. Penelitian ini menggunakan 
tiga matriks $H O Q$ untuk menghasilkan hasil analisis yang optimal. Matriks ini dibuat berdasarkan penggabungan pengolahan data dari penentuan derajat kepentingan sampai dengan interaksi parameter teknik, akan tetapi hasil dari matriks ini belum sepenuhnya dapat diterapkan pada operasional perusahaan. Dalam rangka mengupayakan agar hasil dari metode QFD ini sempurna dan lebih spesifik, maka hasil matriks $H O Q$ diolah lagi hingga dihasilkan output yang benar-benar spesifik, operasional, teknis dan jelas. Output HOQ ini (parameter teknik) akan menjadi input bagi matriks $H O Q$ selanjutnya, dan nilai parameter teknik tersebut menjadi sarana normalisasi bobot bagi matriks $H O Q$ selanjutnya. Matriks $H O Q$ dari produk susu murni kemasan dan yoghurt PT MSA tersaji dalam Gambar 4 dan Gambar 5 (dalam lampiran). Berikut ini akan disajikan analisis komprehensif terhadap pengembangan produk di PT MSA berdasarkan matriks yang sudah dibuat.

Derajat kepentingan digunakan untuk memposisikan setiap keinginan konsumen dalam bentuk data kualitatif dengan tujuan untuk memprioritaskan keinginan konsumen. Pemberian bobot dimulai dari atribut yang sangat penting dengan nilai 4 sampai atribut yang sangat tidak penting dengan nilai 1. Nilai derajat kepentingan relatif atribut produk dapat dijadikan acuan untuk memberikan gambaran informasi atribut produk susu murni mana yang perlu dikembangkan oleh pihak manajemen PT MSA sesuai dengan keinginan konsumen. Nilai derajat kepentingan relatif tertinggi untuk produk susu murni kemasan adalah atribut susu murni kemasan memiliki volume susu murni 1 cup dengan ukuran 225 ml. Nilai derajat kepentingan relatif tertinggi untuk atribut produk yoghurt pada PT MSA adalah atribut kandungan gizi yoghurt mencukupi dan harga yoghurt yang terjangkau oleh masyarakat. Kinerja atribut produk perusahaan dari sudat pandang konsumen dipergunakan untuk menentukan besarnya nilai target oleh pihak manajemen.

Nilai target perlu ditentukan oleh manajemen untuk setiap kinerja atribut produk yang dinilai oleh konsumen, sehingga dapat dijadikan acuan untuk menetapkan nilai target atribut dari perusahaan. Penetapan nilai target harus sesuai dengan kelebihan dan kelemahan perusahaan, dengan mempertimbangkan kondisi internal dan eksternal perusahaan. Dari matriks $H O Q$, terlihat bahwa nilai target yang ditetapkan oleh PT MSA untuk produk susu murni kemasan dan yoghurt sangat tinggi. Sebagian besar target yang ditetapkan, memiliki nilai yang lebih tinggi dari nilai kinerja pelayanan, sehingga akan terjadi perbaikan yang cukup banyak yang harus dilakukan oleh manajemen PT MSA. Nilai rasio perbaikan merupakan hasil bagi antara nilai target dengan kinerja pelayanan.

Rasio perbaikan bertujuan untuk mengetahui nilai yang harus dicapai oleh manajemen perusahaan. Bila nilai kinerja lebih besar atau sama dengan nilai target, maka tidak perlu perbaikan. Rasio perbaikan dengan nilai lebih dari satu berarti bahwa target lebih besar dari nilai kinerja, sehingga perlu adanya perbaikan. Semakin besar nilai rasio perbaikannya maka semakin besar pula tingkat perbaikan yang harus dilakukan. Dari matriks $H O Q$, terdapat lima atribut produk yang nilainya kurang dari 
1 yaitu atribut susu murni kemasan memiliki banyak variasi rasa, merek susu murni kemasan mudah diingat, area pemasaran susu murni kemasan khusus untuk daerah Bandung, lokasi penjualan susu murni kemasan dapat ditemui di mana saja dan gudang penyimpanan susu murni mudah dijangkau. Sedangkan untuk atribut produk yoghurt, terdapat lima atribut yang memiliki nilai kurang dari yaitu merek yoghurt mudah diingat, informasi kadaluarsa yoghurt tertera dengan jelas pada kemasan, ada diskon khusus untuk pembelian dalam kuantitas yang banyak, khusus agen pembayaran dapat dilakukan dengan tempo dan gudang penyimpanan yoghurt mudah dijangkau. Dengan demikian, untuk atribut-atribut tersebut perlu perbaikan yang harus dilakukan oleh manajemen PT MSA.

Sales point ditentukan oleh pihak perusahaan berdasarkan pada setiap atribut yang dapat memengaruhi nilai penjualan. Sales point mengindikasikan kemampuan menjual produk, yang didasarkan pada seberapa jauh kebutuhan konsumen dapat dipenuhi. Sales point merepresentasikan penilaian manajemen PT MSA terhadap atribut-atribut produk, yang didasarkan pada sejauh mana atribut-atribut tersebut mempunyai nilai jual bagi pihak perusahaan. Atribut produk susu murni kemasan yang mempunyai nilai jual tinggi berjumlah empat belas atribut. Sedangkan atribut yang memiliki nilai jual sedang berjumlah satu atribut yaitu atribut tentang merek susu murni kemasan mudah diingat. Atribut produk yoghurt yang mempunyai nilai jual tinggi berjumlah tiga belas atribut, sedangkan atribut yang memiliki nilai jual sedang berjumlah dua atribut yaitu atribut tentang merek yoghurt mudah diingat dan artibut tentang promosi produk yoghurt melalui media lokal dan langsung ke konsumen. Atribut produk yang akan ditingkatkan dan dikembangkan perlu ditentukan bobot prioritas atribut produk tersebut. Dengan mengetahui prioritas pengembangan atribut produk, maka dapat ditentukan urutan atribut mana yang akan ditingkatkan dan dikembangkan.

Perhitungan bobot yang sudah diperoleh perlu untuk dinormalisasikan. Normalisasi bobot bertujuan untuk memudahkan penentuan prioritas pengembangan atribut yang perlu segera mendapat pengembangan. Normalisasi bobot dihitung dengan membagi bobot dengan total bobot. Dari hasil perhitungan, diperoleh nilai total bobot susu murni kemasan adalah sebesar 78.376, dan total bobot untuk yoghurt adalah sebesar 76.435. Prioritas pengembangan atribut produk susu murni kemasan dan yoghurt yang perlu segera mendapat pengembangan adalah atribut merek susu murni kemasan dan yoghurt mudah diingat, sehingga PT MSA perlu melakukan peninjauan ulang atas merek produk.

Parameter teknik merupakan hasil menerjemahkan keinginan konsumen menjadi bahasa teknik yang dapat diukur untuk menentukan target yang akan dicapai dan untuk menentukan atribut mana yang nantinya akan dikembangkan. Untuk menentukan parameter mana yang harus dinaikkan atau diturunkan, diperlukan wawancara dan konsultasi dengan pihak manajemen perusahaan, untuk mengetahui parameter teknik yang sesuai dengan keinginan konsumen. 
Tahap selanjutnya adalah interaksi antara keinginan konsumen dengan parameter teknik. Tahap ini dimaksudkan untuk mengetahui keeratan hubungan masing-masing komponen parameter teknik dalam memenuhi keinginan konsumen. Tiga tipe hubungan yang digunakan adalah hubungan kuat, hubungan sedang dan hubungan lemah. Tahapan selanjutnya adalah membuat matriks interaksi untuk menghubungkan antara atribut produk yang dianggap penting oleh konsumen dengan parameter teknik yang telah disusun. Lemah atau kuatnya interaksi yang terjadi dipengaruhi oleh tingkat kedekatan antara atribut produk dengan parameter teknik. Interaksi yang terjadi kemudian dinyatakan dalam angka dan simbol. Interaksi ini harus dikalikan dengan normalisasi bobot dari setiap atribut yang telah dihitung sebelumnya, sehingga menghasilkan nilai untuk setiap parameter teknik dan atribut produk. Nilai ini kemudian dijumlahkan, sehingga diketahui total setiap parameter teknik. Setelah diketahui nilai setiap parameter teknik, maka dapat ditentukan parameter teknik mana yang menjadi prioritas untuk dikembangkan terlebih dahulu. Atribut produk harus diubah kedalam bahasa teknik yang lebih mudah untuk dipahami oleh manajemen.

Sejumlah lima belas atribut produk susu murni diterjemahkan menjadi sembilan jenis parameter teknik. Parameter teknik tersebut cukup berhubungan dengan pengolahan produk agar sesuai dengan kebutuhan dan keinginan konsumen. Hubungan yang terjadi antara atribut produk dengan parameter teknik berupa hubungan kuat dengan nilai sembilan yaitu hubungan antara kandungan gizi susu murni jauh lebih bagus dibandingkan dengan kandungan gizi susu formula, serta penerimaan bahan baku susu murni. Hubungan moderat dengan nilai tiga misalnya terjadi antara kandungan gizi susu murni yang jauh lebih bagus dibandingkan dengan kandungan gizi susu formula. Hubungan dengan nilai satu merupakan hubungan lemah, misalnya hubungan antara promosi produk susu murni melalui media lokal dan langsung ke konsumen dengan penerimaan bahan baku susu murni.

Sejumlah lima belas atribut produk yoghurt diterjemahkan menjadi delapan jenis parameter teknik. Parameter teknik tersebut cukup berhubungan dengan pengolahan produk agar sesuai dengan kebutuhan dan keinginan konsumen. Hubungan yang terjadi antara atribut produk dengan parameter teknik berupa hubungan kuat dengan nilai sembilan yaitu hubungan antara kandungan gizi yoghurt mencukupi dengan proses inkubasi antara dua belas sampai empat belas jam pada susu ruang. Hubungan moderat dengan nilai tiga misalnya terjadi antara harga yoghurt terjangkau oleh masyarakat dengan proses pengemasan. Hubungan dengan nilai satu merupakan hubungan lemah, misalnya hubungan antara lokasi penjualan yoghurt dapat ditemui dimana saja dengan bahan baku susu murni. Nilai matriks interaksi untuk masing-masing atribut harus diketahui karena nilai inilah yang dibutuhkan untuk menentukan ranking. Sedangkan perhitungan tingkat kepentingan relatif dari parameter teknik diperoleh dari hasil bagi antara masing-masing 
parameter teknik absolut dengan jumlah total dari parameter teknik absolut dikalikan 100 persen.

Identifikasi hubungan antar parameter teknik perlu dilakukan guna mengetahui adanya pertukaran antara masing-masing atribut pada parameter teknik. Hubungan positif kuat terjadi apabila dua atribut tersebut masing-masing saling mendukung dalam pelaksanaannya, dan sifat hubungannya sangat kuat. Contoh pada produk yoghurt yaitu hubungan antara kandungan gizi yoghurt mencukupi dengan proses inkubasi antara dua belas sampai empat belas jam pada suhu ruang. Dikatakan hubungan yang bersifat positif kuat, karena proses inkubasi akan memengaruhi kandungan gizi yoghurt. Hubungan positif moderat yaitu apabila masing-masing saling mendukung dalam pelaksanaannya dengan sifat hubungan sedang. Contoh pada produk susu murni kemasan yaitu hubungan kandungan gizi susu murni jauh lebih bagus dibandingkan dengan kandungan gizi susu formula dengan homogenisasi yaitu proses pencampuran bahan tambahan dan aroma. Dikatakan hubungan positif moderat, karena dengan proses pencampuran bahan tambahan dan aroma maka kandungan gizi susu murni terjaga sehingga jauh lebih bagus dibandingkan dengan kandungan gizi susu formula. Dikatakan tidak ada hubungan apabila dua atribut masing-masing tidak terdapat hubungan apapun. Contoh untuk produk yoghurt yaitu hubungan antara lokasi penjualan yoghurt yang dapat ditemui dimana saja dengan bahan baku susu murni, dikatakan tidak ada hubungan karena untuk dua atribut tersebut memang masing-masing mempunyai tujuan yang berbeda.

\section{Keputusan Bisnis PT MSA}

Dalam upaya meningkatkan penjualan, PT MSA melakukan pengembangan produk yoghurt berdasarkan metode Quality Function Deployment (QFD). Selain meningkatkan total penjualan, produksi yoghurt juga bertujuan untuk mengatasi kelemahan pemasaran susu murni pasteurisasi pada segmen supermarket dan perumahan yang memiliki kemungkinan retur produk yang tinggi. Berdasarkan metode Quality Function Deployment (QFD), pemilihan antara produk susu murni kemasan dan yoghurt, diambil keputusan adalah yoghurt. Dimana urutan prioritas lima prosedur kualitas produk yoghurt adalah kandungan gizi yoghurt mencukupi, harga yoghurt terjangkau oleh masyarakat, lokasi penjualan yoghurt dapat ditemui di mana saja, yoghurt memiliki banyak variasi rasa dan penjualan produk yoghurt langsung ke masyarakat.

\section{Implementasi Hasil Penelitian}

Dalam rangka perbaikan kualitas produk, PT MSA telah melakukan perbaikan pada aspek bahan baku, pengembangan kerjasama, perbaikan kemasan dan penciptaan merek dagang. Adapun perbaikan-perbaikan tersebut secara lebih terperinci diuraikan sebagai berikut. 
a. Penggunaan bahan baku susu murni yang berkualitas tinggi. Dengan susu murni yang berkualitas tinggi, produk susu murni kemasan maupun yoghurt yang dihasilkan juga akan berkualitas tinggi.

b. Membina kerjasama dengan dinas peternakan setempat untuk meningkatkan cara beternak sapi yang baik dan benar.

c. Membina kerjasama dengan peternak-peternak yang lain melalui Koperasi Peternak Susu Bandung Utara (KPSBU).

d. Memperbaiki kemasan, dengan menggunakan bahan yang tidak mudah sobek dan tahan lama, pencantuman ijin dari departemen kesehatan dan komposisi produk.

e. Menciptakan merek dagang. Pemberian merek dagang perlu memperhatikan bahwa nama merek harus unik dan mudah diingat, serta tidak boleh sama dengan merek perusahaan lain.

f. Melakukan kerjasama dengan perbankan untuk mengatasi masalah modal.

PT MSA menggunakan metode Quality Function Deployment (QFD) dalam menentukan pengembangan produk susu murni menjadi susu murni kemasan dan yoghurt. Berdasarkan metode $Q F D$, maka dipilih produk yoghurt dengan urutan prioritas kandungan gizi yoghurt mencukupi, harga yoghurt terjangkau oleh masyarakat, lokasi penjualan yoghurt yang dapat ditemui di mana saja, yoghurt memiliki banyak variasi rasa, penjualan produk yoghurt langsung ke masyarakat, area pemasaran yoghurt khusus untuk daerah Bandung, pengenalan produk yoghurt melalui pameran-pameran, volume yoghurt 1 cup sebesar $240 \mathrm{ml}$, distribusi yoghurt langsung ke konsumen atau agen-agen dan pembayaran dengan tempo untuk agen. Terkait masalah harga, PT MSA telah melakukan penyesuaian antara harga dengan proses produksi, dimana elastisitas harga disesuaikan dengan permintaan pasar. Dalam hal saluran pemasaran, PT MSA mulai menerapkan sistem distribusi langsung. Jika semula melalui perantara, sebagian proses distribusi mulai dilakukan secara langsung. Selain itu, dilakukan perbaikan kemasan, variasi rasa dan tingkat keasaman yang akan menambah nilai tambah produk. PT MSA selanjutnya dapat menjual langsung ke konsumen akhir, restoran maupun supermarket. Dengan begitu harga jual bisa dinaikkan sehingga meningkatkan laba perusahaan. Kegiatan promosi mulai ditingkatkan, misalnya saja dengan mengikuti pameran, melalui media sosial seperti Facebook dan Twitter. Hal ini dilakukan untuk menarik minat konsumen dari luar kota agar bisa mengetahui informasi tentang produk PT MSA.

Strategi perluasan pasar pada dasarnya merupakan upaya menambah jangkauan pemasaran dari jenis barang yang sekarang telah diproduksi. Hal ini dapat dilakukan dengan cara menambah pasar sasaran, memodifikasi saluran distribusi dan menambah intensitas promosi. Perusahaan dapat memperluas wilayah pemasaran secara bertahap dari pasar lokal, regional dan nasional. PT MSA dapat melakukan penambahan pasar sasaran yang semula hanya daerah Bandung bisa dikembangkan ke wilayah Jawa Barat yang lain. 
PT MSA memiliki strategi untuk melakukan perubahan produk secara substansial. Bahkan, jika perlu perusahaan bersedia mengembangkan produk baru, sekalipun jarang sampai pada tahapan benar-benar mencipta produk baru (inovasi baru). Produk baru tersebut masih terikat dengan produk yang lama, dimana perubahan ini menyangkut karakter (ciri) dan atribut produk. Secara terperinci, strategi pengembangan produk dapat dilakukan dengan berbagai cara berikut ini.

a. Mengembangkan (mengubah) ciri dari atribut produk, dengan teknik adaptasi, modifikasi (warna, aroma, bentuk, rasa), menambah (besar, berat), mengurangi, mengganti (bahan baku, proses), mengatur ulang (pola, tata letak, komponen), membalik (lokasi yang sebelumnya tidak lazim) atau kombinasi.

b. Mengembangkan produk yang memiliki berbagai tingkatan kualitas. Teknik ini memiliki kelemahan yaitu dapat memberikan kerancuan akan reputasi dan citra perusahaan. Kelemahan ini akan semakin nyata dalam hal perusahaan tersebut sudah memiliki reputasi sebagai penghasil produk yang berkualitas tinggi. Hal ini bisa mengakibatkan persepsi yang bias, sehingga perusahaan mengalami penurunan kualitas yang ujungnya membuat konsumen kecewa dan beralih ke produk pesaing.

c. Mengembangkan produk dengan berbagai ukuran dan model. Strategi ini cenderung tepat diterapkan pada produk yang dituntut untuk terus mengikuti perkembangan selera konsumen. Target pasar yang disasar memiliki tingkat perubahan yang relatif cepat dalam waktu yang relatif pendek. Perusahaan yang mampu mengikuti perubahan tersebut, memiliki peluang untuk memperoleh laba yang tinggi.

d. Inovasi produk. Pilihan ini memiliki risiko kegagalan yang cenderung tinggi. Konsumen jugan memiliki ekspektasi akan adanya inovasi produk secara periodik. Perusahaan akan memiliki kemungkinan menikmati laba yang besar pada saat produk tersebut dapat diterima masyarakat luas.

\section{SIMPULAN}

PT MSA menggunakan QFD dalam pengembangan produk susu murni menjadi susu murni kemasan dan yoghurt. Motivasi PT MSA dalam melaksanakan pengembangan produk terdiri dari beberapa aspek, antara lain kemajuan ilmu pengetahuan dan teknologi, perubahan permintaan dari konsumen, persaingan, keinginan untuk meningkatkan laba serta mempertahankan posisi pasar. Dalam rangka pengembangan produk baru tersebut, telah dilakukan analisis QFD yang membandingan antara produk susu murni kemasan dan yoghurt. Berdasarkan penelitian yang dilakukan, diperoleh lima belas atribut produk yang diinginkan konsumen. Atribut produk susu murni kemasan dan yoghurt yang dianggap penting oleh konsumen yaitu kandungan gizi, variasi rasa, merek, informasi kadaluarsa, 
volume, harga, diskon khusus, sistem pembayaran, distribusi, area pemasaran, lokasi penjualan, gudang penyimpanan, pengenalan produk, promosi produk dan penjualan langsung. Atribut produk susu murni kemasan yang dianggap penting oleh konsumen adalah volume susu murni dalam kemasan cup dengan ukuran 225 ml. Sedangkan atribut produk yoghurt yang dianggap penting oleh konsumen adalah kandungan gizi yoghurt yang mencukupi dan keterjangkauan harga oleh masyarakat. Pengembangan produk susu murni kemasan agar sesuai dengan keinginan konsumen dilakukan dengan mengikuti urutan prioritas prosedur kualitas hasil analisis QFD. Urutan prioritas sepuluh prosedur kualitas dari lima belas atribut tersebut adalah volume, pengenalan produk, penjualan langsung, harga, cara pembayaran, kandungan gizi, informasi kadaluarsa, diskon khusus, distribusi dan variasi rasa. Sedangkan untuk produk yoghurt yaitu kandungan gizi, harga, lokasi penjualan, variasi rasa, penjualan langsung, area pemasaran, pengenalan produk, volume, distribusi dan cara pembayaran.

Metoda analisis yang digunakan dalam penelitian ini adalah QFD (Quality Function Deployment) dengan menggunakan matriks HOQ (House Of Quality). Dalam upaya peningkatan kualitas produk, akan lebih baik bagi produsen jika menggunakan semua tahapan dari metode QFD. Dalam rangka memenuhi kebutuhan dan keinginan konsumen akan perbaikan kualitas produk, perlu dilakukan dukungan dari berbagai pihak. Peningkatan dukungan sumber daya manusia dalam rangka perbaikan kualitas produksi juga perlu diupayakan, misalnya dengan mengadakan pelatihan manajemen, keuangan, pengolahan informasi, penggunaan teknologi serta dukungan fasilitas penunjang. Berdasarkan hasil analisis QFD, sebaiknya manajemen PT MSA melakukan pengembangan produk berdasarkan prosedur kualitas hasil dari pengolahan dan analisis QFD agar sesuai dengan keinginan konsumen. Pengembangan produk PT MSA perlu dilakukan mengingat tidak berkembangnya perolehan laba perusahaan selama ini.

\section{DAFTAR PUSTAKA}

Ariani, D. W. 2008. Manajemen Kualitas. Universitas Terbuka. Jakarta.

Aries, S., dan E. Febru. 2010. Penelitian Tindakan Kelas: Teori dan Aplikasinya. Yogyakarta: Penerbit Aditya Media Publishing.

Arikunto, S. 2006. Prosedur Penelitian Suatu Pendekatan Praktik. Jakarta: Rineka Cipta.

Artiprasetyo, A. 2009. Analisis strategi terhadap penurunan penjualan dan laba pada perusahaan jamu kemasan. Bogor. Available at http://repository.ipb.ac.id/handle/123456789/11205

Crawford, M., dan A. D. Benedetto. 2006. New Product Management. McGraw-Hill International Edition. 
Gaspersz, V. 2006. Total Quality Management Untuk Praktisi Bisnis dan Industri. Jakarta: PT Gramedia Pustaka Utama.

Groover, Mikell P. 2014. Automation, Production System, and Computer-Integrated Manufacturing. Edisi Ke Empat. New Jersey: Prentice-Hall International.

Hermawan, R. 2010. Penelitian Tindakan Kelas SD. Bandung: UPI Press.

Kotler, P., dan K. L. Keller. 2009. Manajemen Pemasaran. Terjemahan: Bob Sabran. Edisi 13 Jilid 1 dan 2. Surabaya: Erlangga.

Sugiyono. 2013. Metode Penelitian Bisnis. Bandung: Alfabeta.

Tjiptono, F. 2007. Total Quality Management. Yogyakarta: Andi Offset. 


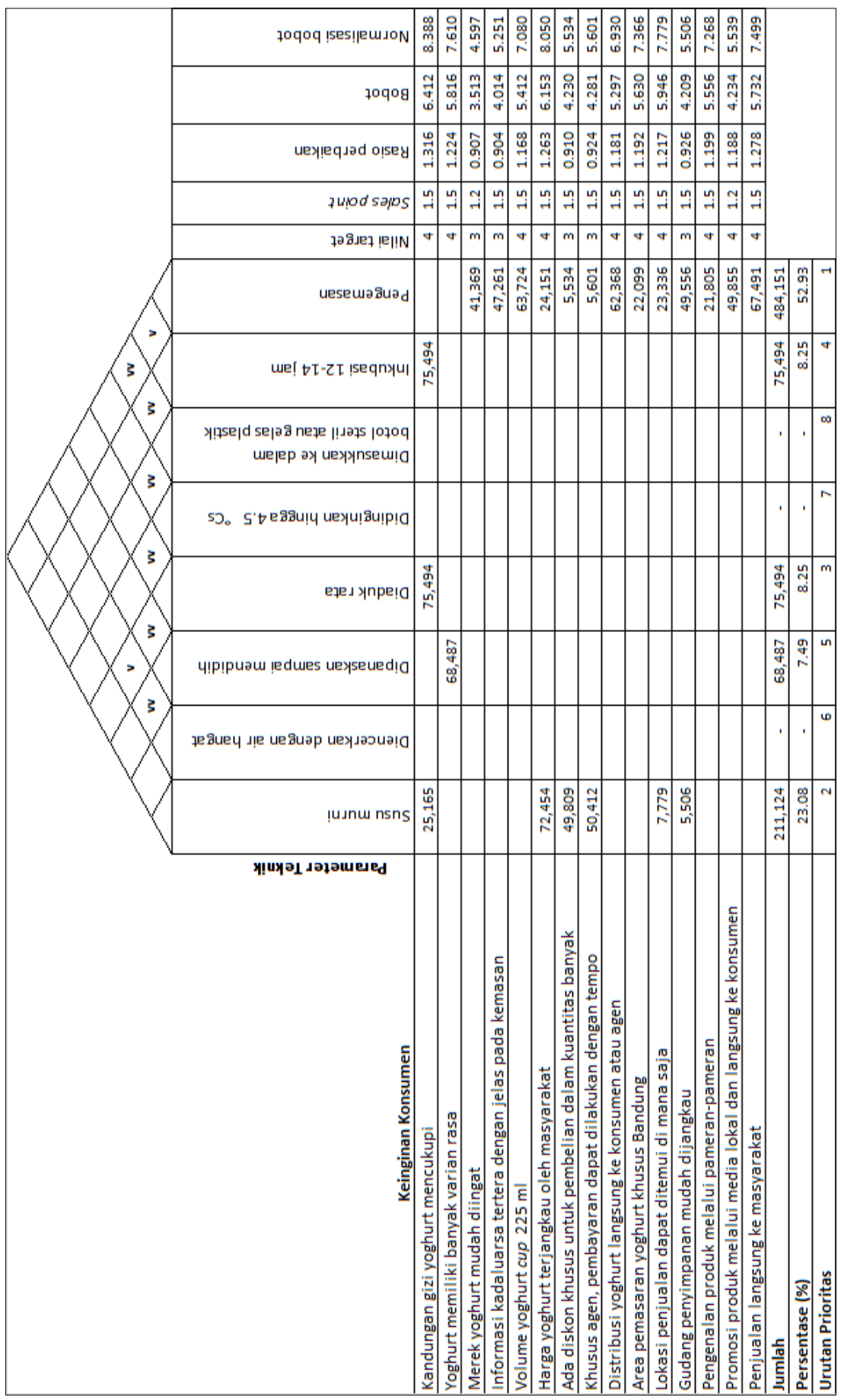

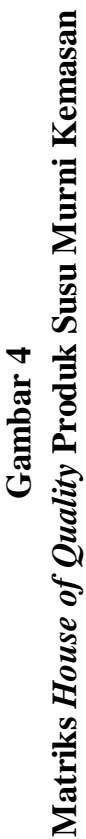




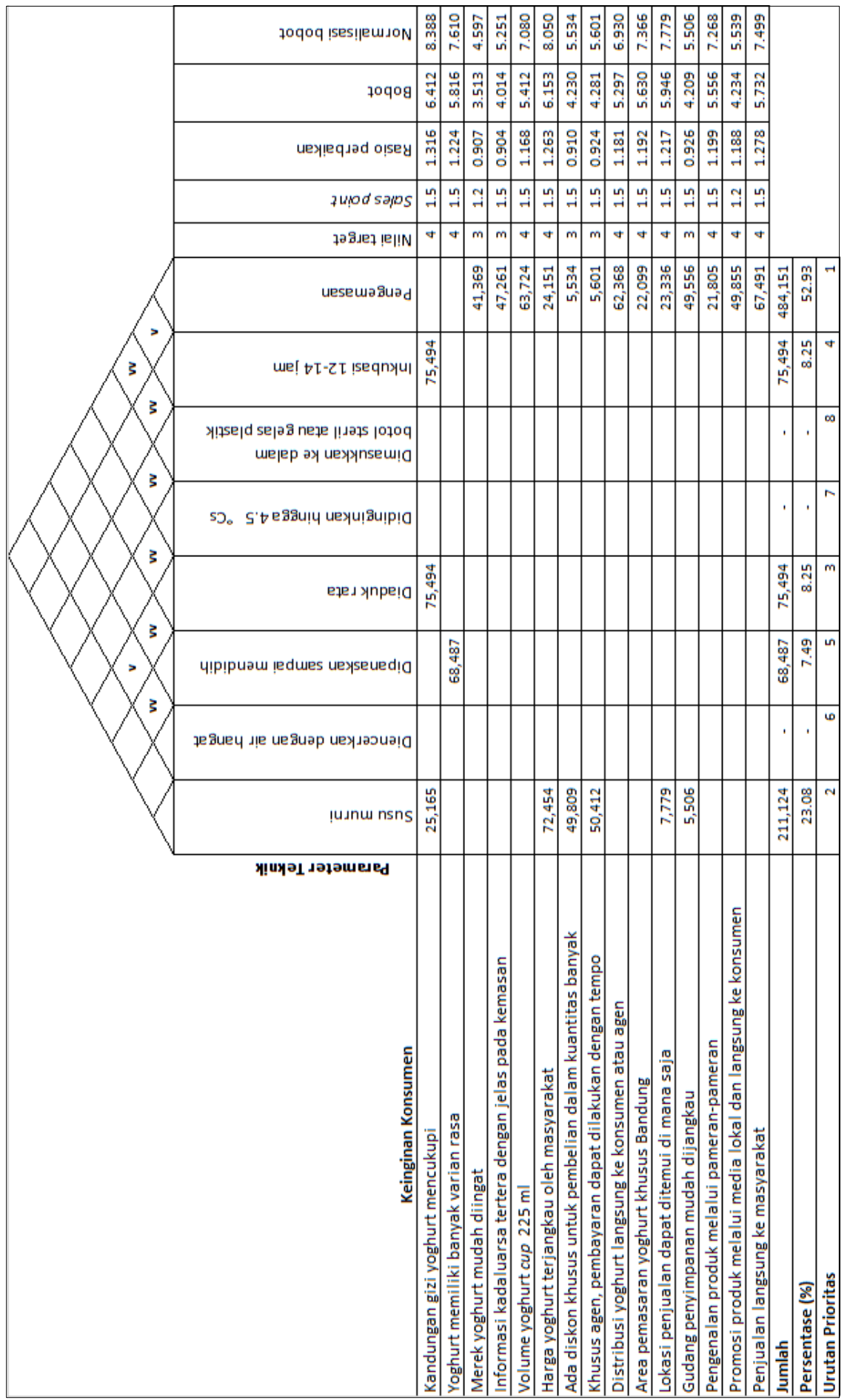

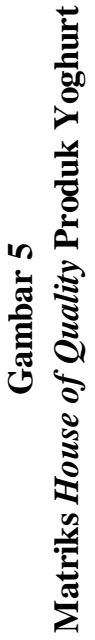


